\title{
Evolution of some physical properties related to soil quality in the degraded ecosystems of "raña" formations from SW Spain
}

\author{
Ignacio Mariscal , Fernando Peregrina, Teshome Terefe, Pedro González, Rafael Espejo
}

\begin{abstract}
The dynamics of some physical properties of the soil: bulk density, porosity and percentage of water stable aggregates, which usually are taken as indicators for evaluation of soil quality, have been studied on the flat surfaces of the Cañamero's "raña" formation (Cáceres, SW Spain). The study shows a high relationship between all these physical soil parameters, the degradation level of the natural vegetation, and years of the soil under tillage. As the deterioration of the natural soil increases the bulk density of the fine earth is increased, diminishing porosity, field capacity moisture content, percentage of water stable aggregates in soil and water infiltration.
\end{abstract}

\section{Introduction}

The ecosystems of the flat surfaces of "raña" formations from SW Spain (Ultisoles by Soil Survey Staff, 2003) have been strongly degraded since the 1940 s as a result of the natural vegetation elimination and unsustainable soil management resulting in a progressive impoverishment in the organic matter content of the A horizon. One of the factors which has contributed to this decrease is the continuous tillage as it can be shown in the soils of the olive grove farms (Mariscal et al., 2005). This change has decreased the initial low productivity of these soils, derived from their unsuitable chemical properties (Espejo, 1993).

The climax vegetation on the flat surfaces of this formation is cork-oak (Quercus suber) (Rivas Godoy, 1964). This cork-oak forest frequently was altered, prior to the great transformation of the 1940 s, by substitution of the cork oak for evergreen oak (Quercus ilex) to feed pigs and sheep. The vegetation type closer to the tree climax is a dense scrub of arbutus (Arbutus unedo) of the association Phillyreo-Arbutetum tipicum (Rivas Godoy, 1964). After successive degradations the edaphic conditions allow the establishment of thicket of the association Genisto-Cistetum landaniferi and the scrub of the association Halimio-Ericetum umbellatae (Rivas Godoy, 1964).

The organic matter (O.M.) content in the upper A horizon is directly related to different physical soil properties which are strongly related to soil quality viz. the percentage of aggregates and their stability (Tisdall and Oades, 1982; Chaney and Swift, 1984; Franzluebbers and Arshad, 1996), bulk density, porosity, water infiltration, and water holding capacity (Hudson, 1994; Moreno et al., 1997). The quality of the soil depends on these properties because they determine the ease of supply of nutrients, water and air, which are so important for the balance of the life in the soil. 
Table 1

Electric conductivity (EC), total organic carbon (TOC), texture, bulk density, porosity, field capacity and infiltration across the land use transect

\begin{tabular}{|c|c|c|c|c|c|c|c|c|}
\hline \multicolumn{8}{|c|}{ Sieved soil $(<2 \mathrm{~mm})$} & \multirow{2}{*}{$\begin{array}{l}\text { Undisturbed } \\
\text { soil } \\
\text { Infiltration } \\
\left(\mathrm{cm} \mathrm{h}^{-1}\right)\end{array}$} \\
\hline $\begin{array}{l}\text { Soil sampled } \\
\text { sites }\end{array}$ & Vegetation & $\begin{array}{l}\text { Total OC } \\
(\%)\end{array}$ & $\begin{array}{l}\mathrm{EC} \\
\left(\mu \mathrm{S} \mathrm{cm} \mathrm{cm}^{-1}\right)\end{array}$ & $\begin{array}{l}\text { Texture } \\
\text { (ISSS) }\end{array}$ & $\begin{array}{l}\text { Bulk density } \\
\left(\mathrm{g} \mathrm{cm}^{-3}\right)\end{array}$ & $\begin{array}{l}\text { Porosity ( } \% \\
\text { v) }\end{array}$ & $\begin{array}{l}\text { Field capacity (water/ } \\
\text { soil) }\end{array}$ & \\
\hline 1 & Cork oak & $4.77 \mathrm{~d} \dagger$ & $96 b$ & Sandy loam & $0.73 \mathrm{a}$ & $72 \mathrm{c}$ & $31.0 \mathrm{~d}$ & $55 \mathrm{c}$ \\
\hline 2 & Evergreen oak & $3.90 \mathrm{c}$ & $95 \mathrm{~b}$ & Sandy loam & $0.79 \mathrm{a}$ & $70 \mathrm{c}$ & $24.9 \mathrm{c}$ & $24 b$ \\
\hline 3 & $\begin{array}{l}\text { C. Ladaniferus } \\
\text { Scrub }\end{array}$ & $2.56 \mathrm{~b}$ & $153 b$ & Sandy loam & $1.00 \mathrm{~b}$ & $62 b$ & $16.2 \mathrm{bc}$ & $29 b$ \\
\hline 4 & 6 years fallow & $2.15 b$ & $31 \mathrm{a}$ & Sandy loam & $1.11 \mathrm{~b}$ & $58 \mathrm{~b}$ & $18.2 \mathrm{c}$ & $26 \mathrm{~b}$ \\
\hline 5 & 3 years fallow & $2.33 b$ & $32 \mathrm{a}$ & Sandy loam & $0.91 \mathrm{ba}$ & $66 b$ & $10.8 b$ & $11 \mathrm{a}$ \\
\hline 6 & Olive grove & $1.72 \mathrm{a}$ & $42 \mathrm{a}$ & Sandy loam & $1.30 \mathrm{c}$ & $57 \mathrm{a}$ & $7.1 \mathrm{a}$ & $11 \mathrm{a} / 4.6^{*}$ \\
\hline
\end{tabular}

†Different letters indicate significant differences according to LSD $(0.05)$.

$4.6^{*} \mathrm{~cm} \mathrm{~h}^{-1}$ is the infiltration in the area of machinery passing.

The objective of this work is to determine how the decrease in organic matter content in these soils has affected to the dynamics of these physical properties in the soils of the Cañamero's "raña" formation.

\section{Materials and methods}

The study was carried out in the flat surface of the head of the Cañamero's "raña" (within $39^{\circ} 22^{\prime}-39^{\circ} 17^{\prime}$ Lat. $N, 5^{\circ} 21^{\prime}-5^{\circ} 16^{\prime}$ Long. E) at an average elevation of $580 \mathrm{~m}$. The mean annual precipitation was $869 \mathrm{~mm}$ and the mean daily air temperature was $15.0{ }^{\circ} \mathrm{C}$. Four samples of the top $10 \mathrm{~cm}$ of the soil under different types of vegetation and land uses were randomly taken from each of the following sites: (1) cork oak more than 100 years old; (2) evergreen oak more than 100 years old; (3) land cultivated about 20 years ago, and covered by a Cistus ladaniferous scrub over $75 \%$ of its surface; (4) land cultivated with rye and in continuous fallow for the last 6 years; (5) land cultivated with rye and in continuous fallow for the last 3 years; (6) land under olive grove, continuously tilled along the last 50 years. The soil sample sites were within an area of about $1.5 \mathrm{~km}^{2}$.

In the fine earth $(<2 \mathrm{~mm})$, the electric conductivity was measured in soil water suspensions of 1:2.5 ratio. The texture of the fine earth after destruction of the O.M. with oxygenated water was determined according to the methodology of Kilmer and Alexander (1949). The bulk density and porosity of the fine earth were determined according to "Soil Quality Test Kit Guide" (USDA, 1999), and the water infiltration was measured in situ (four replicates) following the same guide.

The water content at field capacity was determined in soil columns with free drainage after $48 \mathrm{~h}$ having added a known volume of water. The percentage of water stable aggregates bigger than $250 \mu \mathrm{m}$ was determined according to the methodology of Kemper and Rosenau (1986). All data were analyzed using Analysis of Variances in STATGRAPHICS Plus 4.0.

\section{Results and discussion}

The EC (Table 1), in general is very low as expected in highly leached soils; higher values in samples from soils under the cork oak, evergreen oak and the thicket (soils 1,2 and 3) can be due to their higher content in soluble humic compounds.

The bulk density of the fine earth is closely related to the content of organic matter. The smallest value of bulk density was reached in the soil sample taken under branches of the cork oak which is the richest in organic matter, whereas the highest was in the soil sample from the Ap horizon of the soil from the olive grove, which had the lowest content in organic matter. The porosity is inversely proportional to the bulk density of the fine earth and so is maximal in the soil from the cork oak,

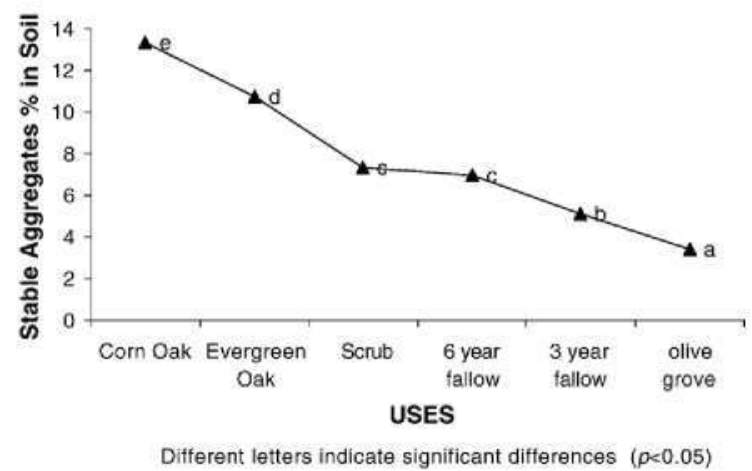

Fig. 1. Percentage of water stable aggregates in soil for the different sampled sites across the land use transect. 
falling from the site 1 to site 6 except for site 5 (fallow of 3 years) that deviates slightly from this tendency.

The water content at field capacity covers a wide range and shows a similar tendency to that of porosity. The percentage of water stable aggregates is also related to the content of organic matter, being maximum in the soil under the cork oak and the lowest in the soil under the olive grove; we attribute the latter effect to continuous annual tillage. Fig. 1 shows the variation of the percentage of water stable aggregates with respect to $100 \mathrm{~g}$ of unaltered soil; this property is a good indicator of the influence of the different forms of land use on the soil.

Water infiltration decreases when the average size of the pores or the total quantity of pores diminishes as a consequence of the destruction of the aggregates, pore obstruction by particles, or saturation by water (Brady and Ray, 2002). A progressive decrease is observed in the value of the infiltration from site 1 (cork oak) to 6 (olive grove). The data for the evergreen oak is anomalous and quite lower than that for cork oak, possibly because of the pressure of the livestock, which crowds around the evergreen oak looking for acorns to eat and thereby sealing the soil pores close to the surface (the selected trees are frequently visited by cattle). In the case of the soil under the olive grove the low infiltration is likely to be related directly to the decrease of the percentage of stable aggregates (Lowery et al., 1996). We highlight that the percentage of the stable aggregate of fine earth exceeds $95 \%$ at all locations except for the olive grove where it only reaches $87 \%$ (data not shown). Nevertheless the methodology used to measure the water infiltration shows high variability among replicate determinations.

\section{Acknowledgements}

The authors are grateful to the Ministry of Science and Education of Spain for funding this work through the Project AGL-4545-C03-02 and to Dr. Bruce C. Ball, from SAC (Scottish Agricultural College), for his help.

\section{References}

Brady NC, Ray RW. The nature and properties of soils. Upper Saddle River, New Jersey: Prentice Hall; 2002. 960 pp.

Chaney K, Swift RS. The influence of organic matter on aggregate stability in some British soils. J Soil Sci 1984;35:223-30.

Espejo R. Factores linitantes de la productividad en las fonnaciones tipo raña de Extremadura central. In: Pinilla A, editor. La raña en España y Portugal. Monografia N 2CSIC, Madrid: CCMA; 1993. p. $377-80$.

Franzluebbers AJ, Arshad MA. Water-stable aggregation and organic matter in four soils under conventional and zero tillage. Can J Soil Sci 1996;76:387-93.

Hudson BD. Soil organic matter and available water capacity. J Soil Water Conserv 1994;49:189-94.

Kemper WD, Rosenau RC. Aggregate stability and size distribution. In: Klute A, editor. Methods of soil analysis. Part 1. 2nd ed. Madison: ASA and SSSA; 1986. p. 425-42.

Kilmer VJ, Alexander LT. Methods of making mechanical analyses of soils. Soil Sci $1949 ; 68: 15-24$.

Lowery B, Arshad MA, Lal R. Hickey WJ. Soil water parameters and soil quality. Ln: Doran $J W$, Jones AJ, editors. Methods for assessing soil quality. Soil Sci Soc Am Spec Publ.Madison, WI: SSSA; 1996. p. 143-57.

Mariscal I., Peregrina F., Ordóñez R., Espejo R. Dinámica del carbono en un ecosistema de Raña. In: II Simposio Nacional. Control de la Degradación de Suelos. R. Jiménez Ballesta A.M. Álvarez González, Madrid, 2005, pp. 135-139.

Moreno F, Pelegrin F, Fernández JE, Murillo JM. Soil plyysical properties, water depletion and crop developinent under traditional and conservation tillage ill soutlern Spain. Soil Tillage Res 1997;41:25-42.

Soil Survey Staff. Soil Taxonony. A basic system of soil classification for making and interpreting soil surveys. Agriculture handbook number 436. 2nd edition. Washington D.C.: U.S. Department of Agriculture; 2003.

Tisdall JM, Oades JM. Organic matter and water stable aggregates in soils. J Soil Sci 1982;33:141-63.

United States Department of Agriculture (USDA). Soil Quality Test Kit Guide; 1999. p. 55-9. (August) 